Western University Scholarship@Western

Centre for the Study of International Economic Centre for the Study of International Economic

Relations Working Papers

Relations

1986

\title{
Some Estimates of Trade Flows in Banking Services
}

France St-Hilaire

John Whalley

Follow this and additional works at: https://ir.lib.uwo.ca/economicscsier_wp

Part of the Economics Commons

Citation of this paper:

St-Hilaire, France, John Whalley. "Some Estimates of Trade Flows in Banking Services." Centre for the Study of International Economic Relations Working Papers, 8615C. London, ON: Department of Economics, University of Western Ontario (1986). 
THE CENTRE FOR THE STUDY OF INTERNATIONAL ECONOMIC RELATIONS

WORKING PAPER NO $8615 \mathrm{C}$

SOME ESTIMATES OF TRADE FLOWS IN BANKING SERVICES

\author{
France St-Hilaire \\ and
}

John Wha11ey

This paper contains preliminary findings from research work still in progress and should not be quoted without prior approval of the authors.

DEPARTMENT OF ECONOMICS

THE UNIVERSITY OF WESTERN ONTARIO LONDON, CANADA

N6A 5C2
Department of Economics Library

JUL 81986

University of Western Ontario 


\title{
Some Estimates of Trade Flows \\ in Banking Services 1
}

\author{
by \\ France St-Hilaire \\ and \\ John Whalley \\ Department of Economics \\ University of Western ontario \\ and \\ Institute for Research in Public Policy \\ cttawa, ontario \\ June 1986
}

$1_{\text {An }}$ earlier version of this paper was presented at a symposium on Trade in Services jointly organized by IRPP, Ottawa, and CSIER, University of Western Ontario, held in ottawa. February 14,1986 . We are grateful to symposium participants for comments, and Herb Grubel for comments on an earlier-draf Economics library Departinent of Economics Library
JUt 81986
University of Western Ontario 


\section{Introduction}

Those who advocate including services in a future GATT negotiating round base their case, in part, on the alleged growing importance of trade in services. These claims are based on estimates of service trade derived from balance of payments (BOP) data, even though it is widely recognized that individual service items cannot be identified in these accounts since they are recorded both as part of merchandise trade estimates and as part of the broader receipts and payment of fees, royalties, and investment income (i.e., invisibles).

This paper presents some estimates of international trade in one key service category, banking services, obtained using an alternative method. In the process, we also raise the conceptual issue as to what the measurement of international trade in banking services should include and perhaps more importantly not include. This issue, it turns out, has substantial relevance to the wider debate on trade in services.

We use IMF data on assets and liabilities of both domestic banks and non-banks with foreign banks, and of foreigners with the domestic banking system to construct measures of the volume of transactions on which banking intermediation services are provided across national borders. We then use estimates of the spread between borrowing and lending rates for depositors and borrowers with the financial institutions involved to estimate the value of international flows of intermediation services. We apportion these estimates between depositors and borrowers; and 
on this basis, make calculations of the value of financial intermediation services traded across national boundaries.

Estimates are presented for three years in the early 1980's for three countries: the U.S., the U.K., and Canada. For the early $1980^{\prime} s$, our calculations suggest that the value of international trade flows in banking services is small. For the U.S.. exports are perhaps around $\$ 3-5$ billion per year.

our approach to measuring trade in banking services recognizes that the main service which banks provide is one of financial intermediation between depositors and borrowers. Depositors and borrowers both use banks to economize on transactions costs in locating one another for the purpose of effecting mutually advantageous trades. Depositors postpone consumption in return for interest payments by borrowers on their deposit. They also pool risks of default, reducing the variance of their expected returns on their savings. International flows of banking services occur where banks located in one country provide financial intermediation services to borrowers or depositors located in other countries.

This may seem to be a relatively straightforward concept on which to base a measure of international flows of banking services, but in the literature on service trade which has appeared thus far, international flows of banking services are often equated with the foreign source income of domestic banks. These, of course, are quite different. Our estimates of exports of banking services by the U.S. of $\$ 3-5$ billion in the early 
$1980^{\prime} s$ with estimates of foreign source income accruing to U.S. banks of $\$ 23.2$ billion for 1977 (the latest year for which official estimates are available; see Whichard (1984)).

The implication for the debate on trade in services is that international flows in banking services may be relatively small; but since the importance of the service trade issue is to a great extent measured in terms of foreign affiliate revenues it may well be overemphasized. The fundamental issue with trade in services which many authors have raised is whether the main issues for service industries in fact relate to questions of establishment rights and discriminatory regulations such as those faced by banks in their international operations. strictly speaking, these are investment rather than trade- related issues, and our estimates seem to confirm this.

I I. Services, Balance of Payments Data, and the Treatment of Banking

In attempting to measure international trade in banking services, the wider issues involved in measuring trade in services are readily apparent. There is little, if any, consensus as to what constitute traded services, and available data is very limited. Definitions of service trade vary between two extremes; one restricted to services which actually cross national borders, the other incorporating all non-merchandise and non-transfer items reported in the Balance of Payments current account.

Nevetheless, the most widely used estimates of service trade 
flows are all based (in one way or another) on Balance of Payments data. These accounts, reported on a national basis, record all transactions between residents of a country and the rest of the world (i.e., flows of real resources, transfers and change in assets or liabilities). The current account of the Bop reports merchandise trade and trade in invisibles. 2 The capital account records all financial transactions.

Table 1 summarizes the main BOP items from the IMF Balance of Payments Manual. Invisibles include a number of more readily identifiable service categories such as travel, transportation and freight. Remaining services appear in one miscellaneous category which includes insurance, fees, commissions, royalties and copyrights, construction services, communications and advertising (see the right-hand inset in Table 1).

Listing these items in this way demonstrates the difficulties in separating service transactions on a functional basis. Various services generate fees, royalties, copyrights and commissions. BOP data does not provide any information on the specific activities from which these arise. Constructing estimates of international services flows for such categories as accounting, data processing, education, engineering, franchising, health care, leasing and renting, mangement consulting, public relations, law and other professional, marketing and technical

2 It is important to note that invisibles refer to transactions which relate neither to goods flows nor to capital movements. 


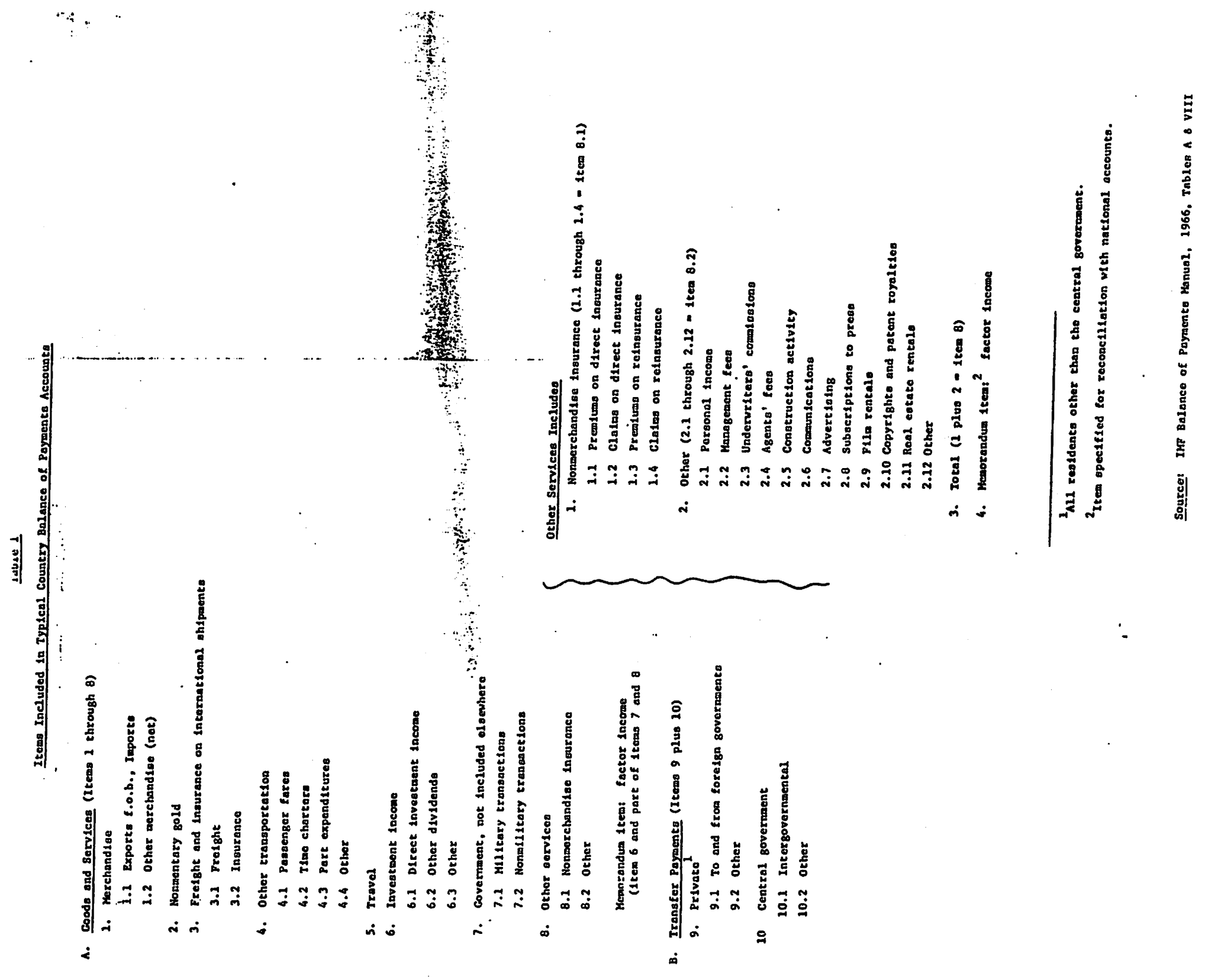


service is simply not possible from BOP. Service transactions in the BOP are recorded by type of service only in a small number of cases (1.e., travel, transportation, insurance). The rest are classified according to the type of payment associated with services provided (e.g., royalties, fees, and commissions). Even the receipts and payments of investment income in effect include a service component. 1

Banking is a good example of these problems. In the U.K. BOP, 2 for instance, the receipts from overseas operations of national banks include the net receipts of banks from services provided to "non-related" customers, (including arbitrage as well as banking charges and commissions); the net receipts for services rendered to overseas branches, subsidiaries and associates of national banks; the net receipts on lending and borrowing involving overseas residents; and the interest, profits and dividends accruing to nationals from overseas branches, subsidiaries and associates of national banks. The first two items are included in "other services", and the second two as

${ }^{1}$ Stalson (1985) refers to "intractable conceptual difficulties" in both collecting and interpreting U.S. data on services.

2 UK Central statistical office, United Kingdom Balance of Payments 1963-73, London. Her Majesty Stationery office, 1974, p. 70 . 
part of investment income. 1

These items, however, do not provide a measure of international trade in banking services, since the service provided by banks is that of financial intermediation. In most cases there is no explicit charge for this service, except for fees and commissions which are relatively minor. The charge for the service is implicit in the difference between the interest rate charged to borrowers, and the rate of interest paid to depositors. The BOP data record estimates of the income flows generated by banks from their international activities and (the value of intermediation services actually traded internationally (except for fees and commission)) is an unidentified portion of these estimates.

Moreover, for the most part, the activities included in the BOP do not relate to transactions which occur between countries. A U.S. bank affiliate acting as a financial intermediary between two non-residents is generating investment income for the parent bank, not engaging in international trade. While one can argue that it is establishing a presence abroad that allows such transactions to occur; and therefore some element of the income return should be included as trade, it is impossible to distinguish the trade element from the investment element.

What is required is a more direct measure of the value

${ }^{1}$ This treatment is approximately the same in the Bop accounts for the U.S. and Canada. The U.K. BOP treatment is described here because of the clear description of sources and methods of construction provided for these accounts. 
of banking services actually traded internationally. Ideally this estimate should include all fees and charges accruing to domestic banks from non-residents, including their foreign affiliates, plus an imputed financial service charge covering the value of intermediation services traded between non-residents; much the same as that used in the National Accounts to measure the value of services rendered by national banks to domestic residents.

II . An Estimate of International Trade Flows in Intermediation Services Provided by Banks Because the BOP estimates do not distinguish the various commonents of receipts and payments associated with banking activities, we have used an alternative method to construct estimates of international trade in intermediation services provided by both domestic and foreign banks. We have done this for three countries (the U.S., the U.K., and Canada), for the years $1982-84$

The method we use involves applying estimates of the spread between deposit and lending rates both for U.S., U.K., and Canadian banks, and banks in their largest partner countries to corresponding data on assets and liabilities of both domestic banks with non-residents, and non resident banks with residents. These yield an estimate of the value of intermediation services provided by domestic banks to both depositors and borrowers abroad, and by non-resident banks to domestic depositors and borrowers. The combined financial intermediation charge is 
apportionned between the parties to calculate the internationally traded component.

International Financial statistics (1985) provides data on inter-country asset and liability positions of resident and nonresident banks. Estimates of intermediation services exported by countries are based on the sum of foreign non-bank deposits with domestic banks (cross-border bank deposits of non-banks by residence of borrowing bank); loans to foreign non banks (crossborder bank credit to non-banks by residence of lending bank): and loans to foreign banks (cross-border inter-bank claims by residence of lending bank). Intermediation services imported by countries are based on the sum of deposits of domestic non-banks with foreign banks (cross border bank deposits of non-banks by residence of depositor); loans to domestic non-banks by foreign banks (cross border bank credit to non banks by residence of borrower); and loans to domestic banks (cross-border inter-bank liabilities by residence of borrowing bank).

Table 2 reports both the consolidated claims and liabilities of domestic banks and non-banks with foreigners, and claims and liabilities of foreign banks involving domestic residents. Data on rate spreads from OECD Financial statistics Monthly are reported in Table 3 . These clearly have to be interpreted with caution; but for the purposes of the calculation we make, are unfortunately all that is available. Data on rate spreads in Japan, for instance, are distorted by domestic financial regulation. Also, the variance in rate spreads by country 


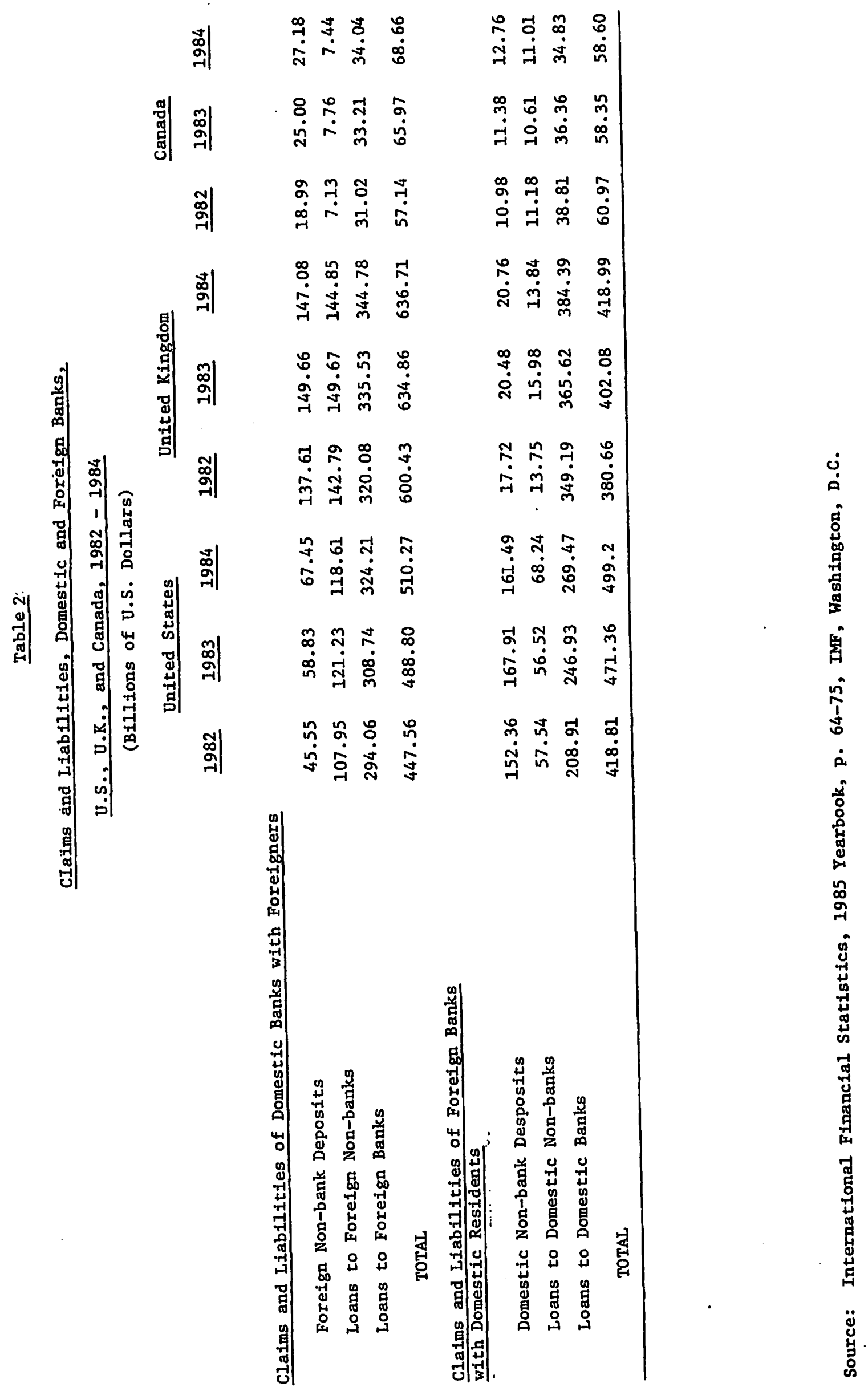


Interest Rate Spreads Between Depositors and Borrowers By Country

$1982,1983,1984$

Countries for which Trade in Intermediation Services are Calculated

United States

1) Large time deposits

2) Prime rate

Implicit service charge

\begin{tabular}{|c|c|c|}
\hline 1982 & 1983 & 1984 \\
\hline $\begin{array}{l}12.27 \\
14.86\end{array}$ & $\begin{array}{r}9.07 \\
10.79\end{array}$ & $\begin{array}{l}10.47 \\
12.05\end{array}$ \\
\hline 1.29 & 0.86 & 0.79 \\
\hline
\end{tabular}

United Kingdom
1) Sterling certificates of deposit $\quad 12.21 \quad 10.08 \quad 9.88$
$\begin{array}{llll}2) & 0 v e r d r a f t & & 9.88 \\ & 12.93 & 10.79 & 10.68\end{array}$
Implicit service charge
$\begin{array}{lll}0.36 & 0.35 & 0.40\end{array}$

Canada
1) 90-day deposit recelpts
14.06
8.25
9.98
2) Chartered banks prime lending rate
15.99
11.23
12.09
Implicit service charge
0.96
1.49
1.05

\section{nther Partner Countries :}

Germany

1) Time deposits (3 months)

2) Discount credits

$\begin{array}{lll}7.54 & 4.56 & 4.86 \\ 9.53 & 6.00 & 6.09 \\ 0.99 & 0.72 & 0.61\end{array}$

Implicit service charge

0.99

$\begin{array}{lll}4.29 & 3.35 & 3.81 \\ 7.14 & 5.82 & 5.91 \\ 1.42 & 1.23 & 1.05\end{array}$

Japan

1) Time deposits ( 1 year)

2) Standard rate

$\begin{array}{lll}5.75 & 5.75 & 5.50 \\ 6.00 & 5.92 & 5.50 \\ 0.12 & 0.08 & 0\end{array}$

\section{France}

1) Time deposits (up to 6 months)

2) Bank's prime lending rate Implicit service charge

$\begin{array}{rrr}9.31 & 8.24 & 7.66 \\ 13.62 & 12.25 & 12.15 \\ 2.16 & 2.01 & 2.24\end{array}$

Belgium

1) Overdrafts with commercial banks

2) 1-year cash certificates Implicit service charge

16.93
9.00
3.97

$\begin{array}{rr}13.68 & 14.41 \\ 8.79 & 8.96 \\ 2.44 & 2.72\end{array}$


reflects both differences in financial regulation across countries, and the form of financial transactions in which the various national banks engage. Spreads are smaller for the U.K. than for most other countries because charges for bank-tobank intermediation services are smaller per dollar transacted than for bank-to-non-bank intermediation and U.K. banks engage in more bank-to-bank intermediation activity.

Despite these problems this data on rate spreads has been used along the consolidated country data on inter-country claims and liabilities reported in Table 2 to estimate the value of intermediation services traded by the U.S., the U.K., and Canada for each of three years. These are reported in Table 4. In making these calculations the value of intermediation services has been apportioned between borrowers and lenders using an equal weighting assumption. Because the number of partner countries is so large in each case, we use data on rate spreads for only the more important countries displayed in Table 3 , and construct weighted averages using the country composition of assets and liabilities.

While clearly dependent on the interest rate spreads used, the striking feature of these estimates of international flows of banking services from Table 4 is their relatively small size. For the U.S., for instance, international trade flows in banking services are in the range of $\$ 3-5$ billion per year in the 1980 's. This contrasts with estimates of foreign affiliate sales of U.S. banks of $\$ 23.2$ billion for 1977 (the latest year 


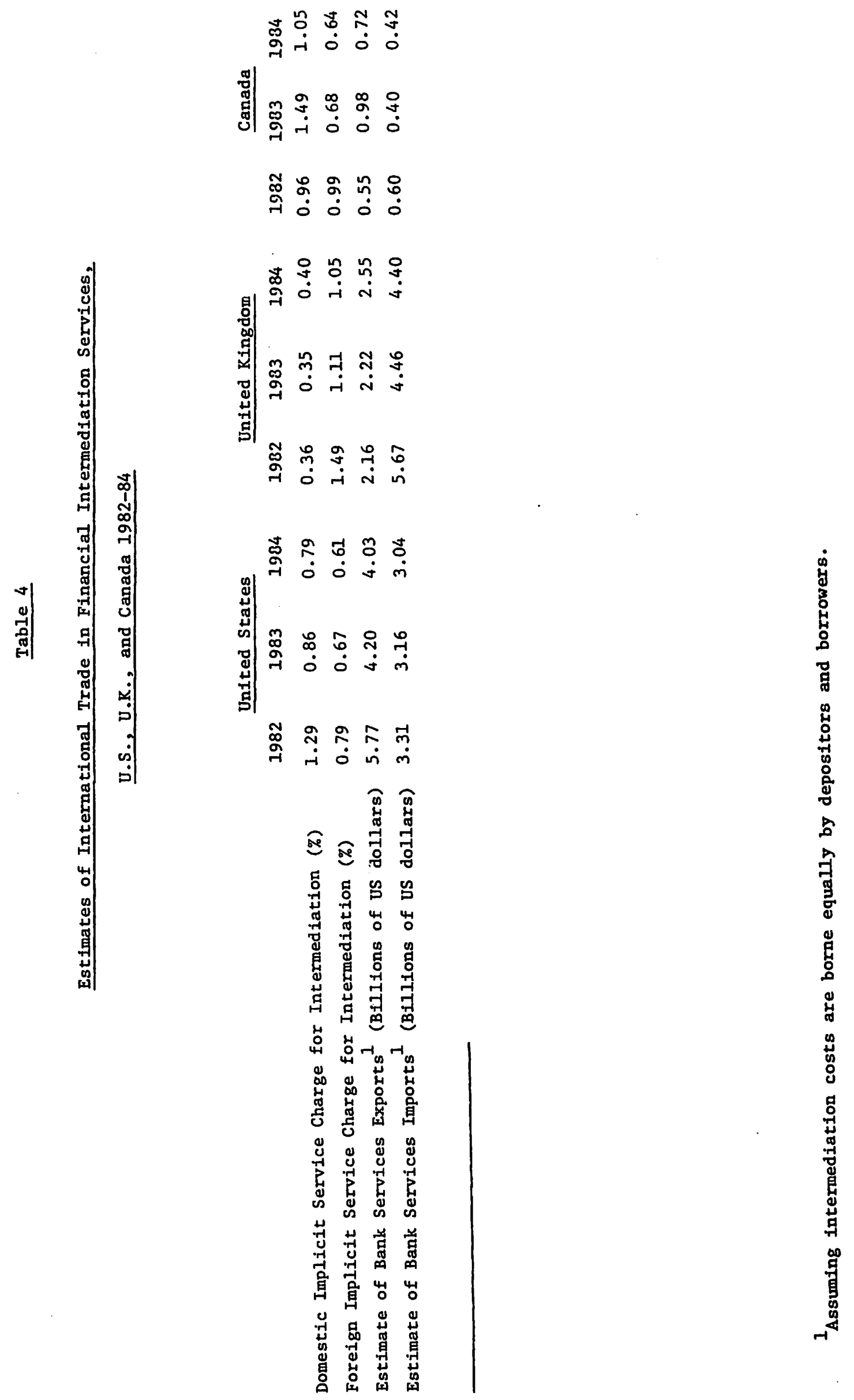


11

available). This difference emphasizes that foreign investment income accruing to U.S. parent banks as a result of operations abroad does not appear to necessarily indicate large international trade in intermediation-type banking services. Service trade, as it relates to banking, may be an important investment issue, but does not appear to be that important a trade issue. 


\section{Bibliography}

Benz, S.F. "Trade Liberalization and the Global service Economy", Journal of World Trade Law, Vol. 19, March/April 1985 .

Dillullo, A.J. "Service Transactions in the U.S. International Accounts, 1970-80", Survey of Current Business, November 1981, p. 29 .

Gibbs, M. "Continuing the International Debate on Services", Journal of World Trade Law, Vol. 190, May/June 1985 .

Hultman, C.W. "International Banking and U.S. Commercial

Policy", Journal of World Trade Law, Vol. 19, May/June 1985. International Financial statistics, 1985 .

International Monetary Fund, Balance of Payments Manual, 3rd Edition, Washington, D.C., 1966 .

OECD. The Internationalisation of Banking: The Policy Issues,

Paris, 1983 .

OECD. Financial statistics Part 1, Paris, January 1983, 1984, 1985 .

OECD. International Trade in Services: Bankinge Identification and Analysis of Obstacles, Paris, 1984 .

Schott, J.J. "Protectionist Threat to Trade and Investment in Services", World Economy, June 1983.

Shelp, R.K. Beyond Industrialization Praeger, New York, 1981 . Stalson, H. U.S. Service Exports and Foreign Barriers: An Agenda for Negotiations, National Planning Association Report No. 219, Washington, D.C., 1985. 
Statistics Canada. The Canadian Balance of International

Payments and International Investment Position: A Description of Sources and Methods, Ottawa, 1982 .

Sunya, D.S. "An Alternative to the Current Treatment of Interest as Transfer in the United Nations and Canadian Systems of National Accounts". The Review of Income and Wealth, Series 30, No. 4, December 1984 .

Task Force on Trade in Services. Background Report, Ottawa, 1982 .

UK Central statistical of ice, United Kingdom Balance of Payments 1963-73, London: Her Majesty's Stationery office, 1974.

U.N.C.T.A.D. Production and Trade in Services: Policies and Their Underlying Factors Bearing Upon International Service Transactions, New York, 1985 .

U.S. Government. U.S. National study on Trade in services. U.S. Government Printing office, 1984 .

U.S. International Trade Commission. The Relationship of Exports in Selected U.S. Service Industries to U.S. Merchandise Exports, Washington, D.C., 1982 .

Whichard, O.G. "U.S. International Trade and Investment in Services: Data Needs and Availability", U.S. Department of Commerce (BEA), Staff Paper 41, Washington, September 1984 . 
8401C Harrison, Glenn W. and Manning, Richard. BEST APPROXIMATE AGGREGATION OF INPUT-OUTPUT SYSTEMS.

$8402 C$ Parkin, Michael. CORE INFLATION: A REVIEW ESSAY.

$8403 \mathrm{C}$ Blomqvist, Áke, and MaMahon, Gary. SIMULATING COMMERICAL POLICY IN A SMALL, OPEN DUAL ECONOMY WITH URBAN UNEMPLOYMENT: A GENERAL EQUILIBRIUM APPROACH.

$8404 \mathrm{C}$ Wonnacott, Ronald. THE THEORY OF TRADE DISCRIMINATION: THE MIRROR IMAGE OF VINERIAN PREFERENCE THEORY?

$8405 C$ Whalley, John. IMPACTS OF A 50\% TARIFF REDUCTION IN AN EIGHT-REGION GLOBAL TRADE MODEL.

8406C Harrison, Glenn W. A GENERAL EQUILIBRIUM ANALYSIS OF TARIFT REDUCTIONS.

$8407 \mathrm{C}$ Horstmann, Ignatius and Markusen, James R. STRATEGIC INVESTMENTS AND . THE DEVELOPMENT OF MULTINATIONALS.

$8408 \mathrm{C}$ Gregory, Allan $w$. and McCurdy, Thomas H. TESTING THE UNBIASEDNESS HYPOTHESIS IN THE FORWARD FOREIGN EXCHANGE MARKET: A SPECIFICATION ANALYSIS.

$8409 \mathrm{C} J o n e s$, Ronald $W$. and KLerzkowsk1, Henryk. NEIGHBORHOOD PRODUCTION STRUCTURES WITH APPLICATIONS TO THE THEORY OF INTERNATIONAL TRADE.

$8410 \mathrm{C}$ Weller, Paul and Yano, Makoto. THE ROLE OF FUTURES MARKETS IN INTERNATIONAL TRADE: A GENERAL EQ̨UILIBRIUM APPROACH.

$8411 \mathrm{C}$ Brecher, Richard A. and Bhagwat1, Jagdish N. VOLUNTARY EXPORT RESTRICTIONS VERSUS IMPORT RESTRICTIONS: A WELFARE-THEORETIC COMPARISON.

8412C Ethier, wilfred J. ILLEGAL IMMIGRATION.

$8413 \mathrm{C}$ Eaton, Jonathon and Gene M. Grossman. OPTIMAL TRADE AND INDUSTRIAL POL ICY UNDER OLIGOPOLY.

8414 C Wooton, Ian. PREFERENTIAL TRADING AGREEMENTS - A 3xn MODEL.

8415C Parkin, Michael. DISCRIMINATING BETWEEN KEYNESIAN AND CLASSICAL THEORIES OF THE BUSINESS CYCLE: JAPAN 1967-1982

8416C Deardorff, Alan V. FIRless FIRwoes: HOW PREFERENCES CAN INTERFERE WITH THE THEOREYS OF INTERNATIONAL TRADE.

$8417 \mathrm{C}$ Greenwood, Jeremy. NONTRADED GOODS, THE TRADE BALANCE, AND THE BALANCE OF PAYRIENTS. 
8418C Blomqvist, Ake and Sharif Mohammad. CONTROLS, CORRUPTION, AND COMPETITIVE RENT-SEEKING IN LDCS.

8419C Grossman, Herschel I. POLICY, RATIONAL EXPECTATIONS, AND POSITIVE ECONOMIC ANALYSIS.

8420C Garber, Peter M. and Robert G. King. DEEP STRUCTURAL EXCAVATION? A CRITIOUUE OF EULER EQUATION METHODS.

8421C Barro, Robert J. THE BEHAVIOR OF U.S. DEFICITS.

8422C Persson, Torsten and Lars E.0. Svensson. INTERNATIONAL BORROWING AND TIME-CONSISTENT FISCAL POLICY.

8423C. Obstfeld Maurice. CAPItAL CONTROLS, THE DUAL EXCHANGE RATE, AND DEVALUATION.

8424C Kuhn, Peter. UNION PRODUCTIVITY EFFECTS AND ECONOMIC EFFICIENCY.

8425C Hamilton, Bob and John Whalley. TAX TREATMENT OF HOUSING IN A DYNAMIC SEOQUENCED GENERAL EỌUILIBRIUM MODEL.

$\$ 426 \mathrm{C}$ Hamilton, Bob, Sharif Mohammad, and John Whalley. RENT SEEKING AND THE NORTH-SOUTH TERMS OF TRADE.

8427C Adams, Charles and Jeremy Greenwood. DUAL EXCHANGE RATE SYSTEMS AND CAPITAL CONTROLS: $\Lambda$ INVESTIGATION.

8428 Loh, Choon Cheong and Michael R. Veall. A NOTE ON SOCIAL SECURITY AND PRIVATE SAVINGS IN SINGAPORE.

8429 Whalley, John. RFGRESSION OR PROGRESSION: THE TAXING OUESTION OF INCIDENCE ANALYSIS.

8430 Kuhn, Peter. WAGES, EFFORT, AND INCENTIVE-COMPATIBILITY IN LIFE-CYCLE EMPLOYMENT CONTRACTS.

8431 Greenwood, Jeremy and Kent P. Kimbrough. AN INVESTIGATION IN THE THEORY OF FOREIGN EXCHANGE CONTROLS.

8432 Greenwood, Jeremy and Kent P. Kimbrough. CAPITAL CONTROLS AND THE INTERNATIONAL TRANSMISSION OF FISCAL POLICY.

8433 . Nguyen, Trien Trien and John Whalley. ẸUILIBRIUM UNDER PRICE CONTROLS WITH ENDOGENOUS TRANSACTIONS COSTS.

8434 Adams, Charles and Russell S. Boyer. EFFICIENCY AND A SIMPLE MODEL OF EXCHANGE RATE DETERMINATION. 
8501C Greenwood, Jeremy and Kent P. Kimbrough. FOREIGN EXCHANGE CONTROLS IN A BLACK MARKET ECONOMY.

8502C Horstmann, Ignatius and James R. Markusen. UP YOUR AVERAGE COST CURVE: INEFFICIENT ENTRY AND THE NEW PROTECTIONISM.

8503C Gregory, Allan $w$. TESTING INTEREST RATE PARITY AND RATIONAL EXPECTATIONS TOR CANADA AND THE UNITED STATES.

$8504 \mathrm{C}$ Kuhn, Peter and Ian Wooton. INTERNATIONAL FACTOR MOVEMENTS IN THE PRESENCE OF A FIXED FACTOR.

8505C Wong, Kar-yiu. GAINS FROM GOODS TRADE AND FACTOR MOBILITY.

8506C Weller, Paul and Makoto Yano. FUTURES MARKETS, REAL INCOME, AND SPOT PRICE VARIABILITY: A GENERAL EỌUIL IBRIUM APPROACH.

8507C Diewert, ..E. THE EFFECTS OF AN INNOVATION: A TRADE THEORY APPROACH.

8508C Ethier, Wilfred J. POREIGN DIRECT INVESTMENT AND THE MULTINATIONAL FIRM.

8509C Dinopoulos, E11as. INSIDE THE BLACK BOX: (IN)TANGIBLE ASSETS, INTRA-INDUSTRY INVESTMENT AND TRADE.

8510C Jones, Richard, John Whalley, and Randall Higle. REGIONAL IMPACTS OF TARIFFS IN CANADA: PRELIMINARY RESULTS FROM A SMALL DIMENSIONAL NUMERICAL GENERAL EOUIL IBRIUM MODEL.

8511C Whalley, John. HIDDEN CHALLENGES IN RECENT APPLIED GENERAL EQQUIL IBRIUM EXERCISES.

8512C Smith, Bruce. SOME COLONIAL EVIDENCE ON THO THEORIES OF MONEY: MARVLAND AND THE CAROLINAS.

8513C Grossman, S.J., A. Melino, and R.J. Shiller. ESTIMATING THE CONTINUOUS TIME CONSUMPTION BASED ASSET PRICING MODEL.

8514C Romer, Paul R. TAX EFFECTS AND TRANSACTION COSTS FOR SHORT TERM MARKET DISCOUNT BONDS. .

8515C McCallum, Bennett T. ON CONSEOUENCES AND CRITJCISMS OF MONETARY TARGETING.

8516C Dinopoulos, Ellas and Ian Wooton. A NORTH-SOUTH MODEL OF INTERNATIONAL JUSTICE.

8517C Huffman, Gregory W. A DYNAMIC EQUILIBRIUM MODEL OF ASSET PRICES AND TRANSACTION VOLUME.

$8518 \mathrm{C}$ Huffman, Gregory W. AN ALTERNATIVE VIEW OF OPTIMAL SEIGNIORAGE.

8519C Huffman, Gregory W. ASSET PRICING WITH HETERGENEOUS ASSETS. 
8435 Kuhn, Peter. UNIONS, ENTREPRENEURSHIP, AND EFFICIENCY.

8436 Hercowitz, Zv1 and Efraim Sadka. ON OPTIMAL CURRENCY. SUBSTITUTION POLICY AND PUBLIC PINANCE.

8437 Lenfosek, Gordon and John Whalley. POLICY EVALUATION IN A SMALL OPEN PRICE TAKING ECONOMY: CANADIAN ENERGY POLICIES.

8438 Aschauer, David and Jeremy Greenwood. MACROECONOMIC EFFECTS OF FISCAL POLICY.

8439C Hercowitz, Zv1. ON THE DETERMINATION OF THE EXTERNAL DEBT: THE CASE OF ISRAEL.

8440C Stern, Robert M. GLOBAL DIMENSIONS AND DETERMINANTS OF INTERNATIONAL TRADE AND INVESTMENT IN SERVICES.

$8441 \mathrm{C}$ Deardorff, Alan V. COMPARATIVE ADVANTAGE AND INTERNATIONAL TRADE AND INVESTMENT IN SERVICES.

8442C Daly, Donald J. TECHNOLOGY TRANSFER AND CANADA'S COMPETITIVE PERFORMANCE.

8443C Grey, Rodney de C. NEGOTIATING ABOUT TRADE AND INVESTMENT IN SERVICES.

8444C Grossman, Gene $M$. and Carl Shapiro. NORMATIVE ISSUES RAISED BY INTERNATIONAL TRADE IN TECHNOLOGY SERVICES.

3445C Chant, John F. THE CANADIAN TREATMENT OF FOREIGN BANKS: A CASE STUDY IN THE WORKINGS OF THE NATIONAL TREATMENT APPROACH.

8446C Aronson, Jonathan D. and Peter F. Cowhey. COMPUTER, DATA PROCESSING, AND COMMUNICATION SERVICES.

8447C Feketakuty, Geza. NEGOTIATING STRATEGIES FOR LIBERALIZING TRADE AND INVESTMENT IN SERVICES.

8448C Harrison, Glenn, W. and E.E. Rutstrom. THE EFFECT OF MANUFACTURING SECTOR PROTECTION ON ASEAN AND AUSTRALIA: A GENERAL EṆUIL IBRIUM ANALYSIS. 
$8520 \mathrm{C}$ Hercowitz, Zvi. THE REAL INTEREST RATE AND AGGREGATE SUPPLY.

8521C Davies, James and Michael Hoy. COMPARING INCOME DISTRIBUTIONS UNDER AVERSION TO DOWNSIDE INEQUALITY.

8522C Nguyen, Trien T. and John Whalley. COEXISTENCE OF EQUILIBRIA ON BLACK AND WHITE MARKETS.

8523C Clarete, Ramon and John Whalley. INTERACTIONS BETWEEN TRADE POLICIES AND DOMESTIC DISTORTIONS: THE PHILIPPINE CASE.

8524C Hamilton, Bob, Sharif Mohammad, and John Whalley. APPLIED GENERAL EQUILIBRIUM ANALYSIS AND PERSPECTIVES ON GROWTH PERFORMANCE.

8525C Huffman, Gregory $W$. THE LAGGED EFFECTS OF POLICY ON THE PRICE LEVEL.

8526C Laidler, David. FISCAL DEFICITS AND INTERNATIONAL MONETARY INST ITUTIONS.

8527C Goodfriend, Marvin. MONETARY MYSTIQUE: SECRECY AND CENTRAL BANKING.

8528C Nguyen, Trien T. and John Whalley. GENERAL EQUILIBRIUM ANALYSIS OF PRICE CONTROLS A TWO-SECTOR COMPUTATIONAL APPROACH.

8529C Heckman, James J. and V. Joseph Hotz. AN INVESTIGATION OF THE LABOR MARKET EARNINGS OF PANAMANIAN MALES: EVALUATING SOURCES OF INEQUALITY.

8530C Greenwood, Jeremy and Gregory W. Huffman. A DYNAMIC EQUILIBRIUM MODEL OF INFLATION AND UNEMPLOYMENT.

8531C Freeman, Scott. INSIDE MONEY, MONETARY CONTRACTIONS, AND WELFARE.

8532C Paderanga, Cayetano Jr. and Ian Wooton. A POSITIVE VIEW OF INFANT INDUSTRIES.

8533C St-Hilaire, France and John Whalley. A MICROCONSISTENT DATA SET FOR CANADA FOR USE IN REGIONAL GENERAL EQUILIBRIUM POLICY ANALYSIS.

8534C Whalley, John. OPERATIONALIZING WALRAS: EXPERIENCE WITH RECENT APPLIED GENERAL EQUILIBRIUM TAX MODELS.

8535C Melvin, James R. THE GENERAL NON-EQUIVALENCE OF TARIFFS AND IMPORT QUOTAS. 
8601C Greenwood, Jeremy and R. Preston McAfee. EXTERNALITIES AND ASYMMETRIC INFORMATION.

8602C Dinopoulos, Elias and Mordechai E. Kreinin. IMPORT ṇUOTAS AND VERS: A COMPARATIVE ANALYSIS IN A THREE-COUNTRY FRAMEWORK.

8603C Clarete, Ramon and John Whalley. COMPARING THE MARGINAL WELFARE COSTS OF COMMODITY AND TRADE TAXES.

8604C Wigle, Randy. CANADIAN TRADE LIBERALIZATION: SCALE ECONOMIES IN A GLOBAL CONTEXT.

8605C Parkin, Michael. DOMESTIC MONETARY INSTITUTIONS AND FISCAL DEFICITS.

8606C Dinopoulos, Elias and Ian Wooton. INTERNATIONAL TRADE AND THE ACQUISITION OF SKILLS.

8607C Kawasaki, Selichi and John McMillan. THE DESIGN OF CONTRACTS: EVIDENCE FROM JAPANESE SUBCONTRACTING.

8608C Williamson, Stephen D. LIQUIDITY, BANKING, AND BANK FAILURES.

8609C Grossman, Gene M. and Carl Shapiro. COUNTERFEIT-PRODUCT TRADE.

8610C Deardorff, Alan V. WHY DO GOVERNMENTS PREFER NONTARIFF BARRIERS?

8611C Horstmann, Ignatius and James R. Markusen. LICENSING VERSUS DIRECT INVESTMENT: A MODEL OF INTERNALIZATION BY THE MULTINATIONAL ENTERPRISE.

8612C Thursby, Jerry G. and Marie C. Thursby. BIlATERAL TRADE FLOWS, THE LINDER HYPOTHESIS, AND EXCHANGE RISK.

8613C Clarete, Ramon and John Wha1ley. EQUILIBRIUM IN THE PRESENCE OF FOREIGN EXCHANGE PREMIA.

8614C Wooton, Ian. TOWARDS A COMMON MARKET: FACTOR MOBILITY IN A CUSTOMS UNION.

8615C St-Hilaire, France and John Whalley. SOME ESTIMATES OF TRADE FLOWS IN BANKING SERVICES. 